DOI https://doi.org/10.30525/978-9934-26-047-6-13

\title{
WATER TREATMENT IN INDUSTRIAL FISHERY
}

\author{
Burhaz M. I.
}

Candidate of Biological Sciences, Associate Professor, Associate Professor at the Aquatic Bioresources and Aquaculture

Department

Odesa State Environment University

\author{
Burhaz O. A. \\ Candidate of Geographical Sciences, \\ Associate Professor at the Environmental Law and Control Department \\ Odesa State Environment University
}

Lichna A. I.

Assistant at the Aquatic Bioresources and Aquaculture Department

Odesa State Environment University

Odesa, Ukraine

Abiotic environmental factors play an important role in a fish life. The main one is the water temperature, which determines the intensity of metabolism and is a natural stimulus that determines the beginning of fish spawning migration, and also it is an indicator of the other factors. Other physical and chemical water properties, such as an oxygen saturation and a presence of other dissolved gases in the water, are also important for fish. One of the main abiotic factors that determine a fish farming efficiency in the industrial farms is the oxygen content in the water.

Water quality in industrial fish farming must meet the following basic requirements: to meet the standards, based on the preservation of the species, fertility and quality of fish offspring; to correspond to the biological characteristics of farmed fish species; to ensure the necessary level of the natural fish forage base development; should not be a source of farm fish diseases; to provide the marketable fish with marketable qualities, preventing the accumulation of dangerous toxicants or pathogens, or the substances that spoil the taste or give the fish an unpleasant odor.

When growing fish water pollution occurs. The source of pollution is both the fish themselves and the various substances coming from outside [2-3]. 
The main source of pollution is certainly the fish itself, which in the process of the life releases various types of waste into the water. Such wastes are mainly feces, mucus, scales. Also uneaten food and various substances that accidentally got into the water from the outside of the fish farm contaminate the water [1].

All pollutants decompose over time releasing nitrogen and other compounds, which disrupt the normal processes of fish life and growth, into the water. Solids that have not completely decomposed are deposited at the bottom of pools, pipelines, in various nodes of fish farms, thereby interfering with the normal water flow and circulation in the system.

Therefore there is a need to remove all suspended contaminants from the water in good time.

Water purification is an integral and main part of water treatment in the fish farms, so when designing a special attention is given to it [2-3].

Water purification in the fish farms can be carried out in different ways.

During the fish farming practice, many different methods of extracting and separating the pollutants from the water were developed.

Conventionally all the methods can be divided into several varieties according to the principle of purification.

It is possible to allocate the basic ones:

- upholding (sedimentation);

- filtering;

- hydrocyclones.

Each of these methods has both advantages and disadvantages and is selected individually for each fish farm.

For example, settling is one of the easiest ways to clean.

This method has advantages over the others in ease of using, but its disadvantage is the relatively large volumes of settling tanks relative to fish ponds and, accordingly, a relatively large area occupied by them.

The method of filtration is more compact compared to settling, but somewhat more difficult to maintain. It means cleaning the filter materials, such as metal or plastic mesh, foam filters, gravel filters and others in good time [2-3].

Hydrocyclones are relatively small - somewhat averaged between the settling tanks and the filtering treatment units. However there are some difficulties that limit their using in water treatment of the fish farms in the calculation and configuration of hydrocyclones.

In their diversity all types of filtering have many different options that can be intertwined and combined with each other, while smoothly moving from one type of filtering to another.

The simplest settling tanks can be complicated and still more efficient [2-3]. 


\title{
References:
}

1. Привезенцев Ю.А. Рыбоводство / Ю.А. Привезенцев, В.А. Власов. -М.: Мир, 2004. 456 с.

2. Шекк П.В. Індустріальне рибництво: підручник /Одеса: 2017. $227 \mathrm{c}$.

3. Електронний

pecypc.

Режим

доступу:

http://www.rybovod.com/ochistka-vody.php

DOI https://doi.org/10.30525/978-9934-26-047-6-14

\section{КЛІМАТИЧНИЙ СТАН ТА ЕКОЛОГІЧНІ ЗМІНИ ГРУНТОВОГО ПОКРИВУ ЗОНИ ЗАХІДНОГО ПОЛІССЯ УКРАЇНИ}

\author{
Гаврилюк В. А. \\ кандидат сільськогосподарських наук, \\ старший науковий співробітник, \\ директор \\ Поліська дослідна станція \\ Наџіонального наукового иентру «Інститут трунтознавства \\ та агрохімії імені О. Н. Соколовського» \\ м. Луиььк, Украӥна \\ Бортнік А. М. \\ кандидат сільськогосподарських наук, \\ стариий науковий співробітник \\ Поліська дослідна станиія \\ Національного наукового иентру «Інститут трунтознавства \\ та агрохімії імені О. Н. Соколовського» \\ м. Луцьк, Украӥна

\section{Мелимука Р. Я.} \\ аспірант \\ Національний науковий центр «Інститут трунтознавства та агрохімії \\ імені О. Н. Соколовського» \\ м. Харків, Україна \\ Родючість - це якісна властивість, яка притаманна лише грунто- \\ вому покриву, та характеризується здатністю безперервно та дос- \\ татньо забезпечувати рослинність одночасно вологою та пожив-
} 54 